\title{
Receptor binding specificity and origin of 2009 H1N1 pandemic influenza virus
}

Wei Hu

Department of Computer Science, Houghton College, Houghton, USA; wei.hu@houghton.edu

Received 31 December 2010; revised 2 February 2011; accepted 3 February 2011.

\section{ABSTRACT}

Recently, a genetic variant of 2009 H1N1 has become the predominant virus circulating in the southern hemisphere, particularly Australia and New Zealand, and in Singapore during the winter of 2010. It was associated with several vaccine breakthroughs and fatal cases. We analyzed three reported mutations D94N, N125D, and $\mathrm{V} 250 \mathrm{~A}$ in the HA protein of this genetic variant. It appeared that the reason for D94N and V250A to occur in pairs was to maintain the HA binding to human type receptor, so the virus could replicate in humans efficiently. Guided by this interpretation, we discovered a new mutation V30A that could compensate for N125D as V250A did for D94N. We demonstrated that the presence of amino acids $30 \mathrm{~A}$ and $125 \mathrm{~N}$ in HA enhanced the binding to human type receptor, while $30 \mathrm{~V}$ and 125D favored the receptors of avian type and of A/South Carolina/1/18 (H1N1). Furthermore, a combination of 94D, 125D, and $250 \mathrm{~V}$ made the primary binding preference similar to that of A/South Carolina/1/18 (H1N1) and a combination of $94 \mathrm{~N}, 125 \mathrm{D}$, and $250 \mathrm{~A}$ resulted in the primary binding affinity for avian type receptor, which clearly differed from that of A/California/07/2009 (H1N1), a strain used in the vaccine for 2009 H1N1. We also re-examined the origin of $2009 \mathrm{H} 1 \mathrm{~N} 1$ to refine our knowledge of this important issue. Although the NP, PA, PB1, and PB2 of 2009 H1N1 were closest to North American swine H3N2 in sequence identity, their interaction patterns were closest to swine H1N1 in North America.

Keywords: 2009 H1N1; Hemagglutinin; Influenza; Informational Spectrum Method; Mutation;

Receptor Binding Specificity

\section{INTRODUCTION}

New influenza viruses arise through genetic reassortment. The 2009 H1N1 virus is a novel virus with its eight gene segments derived from North American and Eurasian swine lineages [1]. Intensive research on this virus has been conducted, including a series of papers of our own [2-12]. These papers covered the mutations and correlated mutations in HA and NA, the stalk motifs in NA, HA receptor binding specificity, novel host markers, interactions of the proteins of 2009 H1N1. Although the World Health Organization (WHO) declared an end to the 2009 H1N1 influenza pandemic on August 10, 2010, continued surveillance of the evolution of the 2009 $\mathrm{H} 1 \mathrm{~N} 1$ virus is still warranted.

The 2009 H1N1 virus remained genetically stable since it emerged in March 2009. However, a genetic variant of 2009 H1N1 was first discovered in Singapore in early 2010, and then was spread to Australia and New Zealand during the 2010 winter influenza season of the southern hemisphere. This variant became the predominant virus circulating in these three countries and was linked to several vaccine breakthroughs and fatal cases. As such, a vaccine update might be needed sooner than expected [13].

Several mutations were identified in genes HA, NA, $\mathrm{PB} 2, \mathrm{~PB} 1, \mathrm{NP}$, and NS1 of this variant, including three mutations D94N, N125D, and V250A in the HA protein. To examine the impact of these mutations, a structural homology model of HA from the A/Brisbane/10/2010 (H1N1) virus based on the A/California/04/2009 (H1N1) structure was constructed. Mutation N125D was found to be centrally located in the classical Sa epitope, potentially affecting antigenicity, and mutation V250A is located at an internal beta sheet below the receptor binding pocket facing the Sa epitope [13]. Additionally, two mutations D94N and V250A tended to occur in pairs in the HA of this variant exclusively circulating in Australia and New Zealand so far [13]. Given the potential significance of the mutations observed in this variant, it is imperative to further investigate their roles in HA recep- 
tor recognition.

In general, human influenza viruses bind preferentially to $\alpha 2,6$ receptors, typically found in the upper airway of humans, whereas avian influenza viruses tend to bind to $\alpha 2,3$ receptors, also found in the lower respiratory tract of humans. It is well documented that mutations in the HA protein may alter HA receptor binding selection. For example, mutations E190D, Q226L, or G228S in H1, H2, or H3 could switch binding preference from avian to human type receptor [14-17]. In [7], the informational spectrum method (ISM) was successfully applied to quantify the effects of mutations in the HA protein on its binding affinity. Position 222 resides in the receptor binding site of the HA protein of 2009 H1N1 and therefore may play a critical role in HA binding specificity. One of the findings in [7] indicated that mutation D222G in the HA of 2009 H1N1 enhances the selection for avian type receptors, and reduces the selection for human type receptors. This finding was subsequently verified in an experiment [18] and mutation D222G was further found to be associated with severe clinical outcome [18-20]. Another recent experiment [21] showed that mutation D94N in H5 HA of avian origin increased the binding of HA to human type receptor, while decreased the binding to avian type receptor.

The purpose of this study was to elucidate the impact of mutations D94N, N125D, and V250A in the HA protein of this variant on receptor affinity with ISM, a bioinformatics technique developed in [7,22-24]. Also we sought to explore the origin of $2009 \mathrm{H} 1 \mathrm{~N} 1$ and its connections with the swine lineages to enrich our understanding of this novel virus.

\section{MATERIALS AND METHODS}

\subsection{Sequence Data}

Protein and gene sequences of influenza were retrieved from the Influenza Virus Resource (http://www. ncbi/nlm.nih.giv/genomes/FLU/FLU.html) of the National Center for Biotechnology Information (NCBI) and the EpiFlu Database (http://platform.gisaid.org) of GISAID. Only the full length and unique sequences were selected. All sequences used in this study were aligned with MAFFT [25].

\subsection{Informational Spectrum Method}

The informational spectrum method is a bioinformatics technique that can be used to analyze protein sequences. Prior to this analysis, the protein sequences have to be translated into numerical sequences. One such approach is to assign each amino acid to its electron-ion interaction potential (EIIP), which represents the average energy of the valence electrons in the amino acid (Table 1). The application of EIIP to protein function analysis assumes that the strength of the electromagnetic field surrounding the protein is indicative of its biological function. This method was successful in revealing various protein properties.

The numerical sequence $x(m)(m=1,2, \cdots)$ of a protein sequence is transformed into the frequency domain using DFT. The DFT coefficients $X(n)$ are defined as

$$
X(n)=\sum x(m) e^{-j\left(\frac{2 \pi}{N}\right) n m} \quad n=1,2, \cdots, N / 2
$$

where $N$ is the length of sequence $x(m)$

The energy density spectrum is defined as

$$
S(n)=X(n) X^{*}(n)=|X(n)|^{2}, \quad n=1,2, \cdots, N / 2
$$

The informational spectrum (IS) of a sequence $x(m)$ comprises the frequencies and the amplitudes of its DFT.

Peak frequencies of IS of a protein sequence reflect its biological or biochemical functions. To determine the same biological or biochemical functions of a group of protein sequences, a consensus informational spectrum (CIS) can be used, which is defined as the product of energy density spectrum $S(n)$ of each sequence in the group. A measure of similarity for each peak is a signalto-noise ratio $(\mathrm{S} / \mathrm{N})$, which is defined as a ratio of signal density to the mean value of the whole spectrum [22]. The theory of CIS [26] states that:

1) One peak only exits for a group of protein sequences sharing the same biological function.

2) No signal peak exists for biologically unrelated protein sequences.

Table 1. The electron-ion interaction potential (EIIP) of amino acids used to encode amino acids.

\begin{tabular}{cccc}
\hline Amino acid & EIIP & Amino acid & EIIP \\
\hline L & 0.0000 & Y & 0.0516 \\
I & 0.0000 & W & 0.0548 \\
N & 0.0036 & Q & 0.0761 \\
G & 0.0050 & M & 0.0823 \\
E & 0.0057 & S & 0.0829 \\
V & 0.0058 & C & 0.0829 \\
P & 0.0198 & T & 0.0941 \\
H & 0.0242 & F & 0.0946 \\
K & 0.0371 & $\mathrm{R}$ & 0.0959 \\
A & 0.0373 & D & 0.1263 \\
\hline
\end{tabular}


3) Peak frequencies are different for different biological functions.

In [7,22-24], it was found that the CIS of HA1 of influenza strains have the following characteristic dominant peaks at different IS frequencies as presented in Table 2.

\section{RESULTS}

\subsection{HA Receptor Specificity Altered by Mutations}

It was observed in [17] that the HA proteins of 2009 H1N1 primarily bind to human type receptors. However, some of them could bind to both human and avian type receptors. Here we are interested in the receptor preferences of the HA proteins of 2009 H1N1 in Singapore ( $n=$ 9) and Oceania $(n=92)$, which were collected after January 1, 2010. The ISM confirmed that the primary binding specificity of both groups was human type receptor at CIS frequency $\mathrm{F}(0.295)$. However, they had different secondary binding frequencies, with the HA proteins from Singapore having $\mathrm{F}(0.258)$ and the HA proteins from Oceania having $\mathrm{F}(0.282)$. To numerically analyze the CIS frequency changes induced by mutations D94N, N125D, and V250A in the HA protein (Figure 1), ISM was applied to the HA sequences of 2009 H1N1 in Singapore (Figure 2). It appeared that N125D increased $\mathrm{F}(0.258)$ and $\mathrm{F}(0.282)$ and decreased $\mathrm{F}(0.295)$ to make $\mathrm{F}(0.258)$ the primary frequency, $\mathrm{D} 94 \mathrm{~N}$ increased $F(0.295)$ and $F(0.282)$ and decreased $F(0.258)$ dramatically, V250A increased $\mathrm{F}(0.258)$ and decreased $\mathrm{F}(0.295)$ to make $\mathrm{F}(0.258)$ the primary frequency. When combined together, D94N and V250A increased F(0.295) and $F(0.282)$ and decreased $F(0.258)$ due to a larger contribution from D94N. It seemed that the biological reason for mutations D94N and V250A to always occur in pairs was to keep $\mathrm{F}(0.295)$ as the primary frequency so the virus could replicate in humans efficiently. It could be inferred that mutation V250A compensated for mutation D94N.

The consequence of mutation N125D was to make $\mathrm{F}(0.258)$ the primary frequency, and the original primary frequency of the HA proteins of 2009 H1N1 in Singapore was $F(0.295)$. We were wondering if there was another mutation in the HA protein that actually could compensate for the effect of N125D to make $F(0.295)$ the primary frequency for the whole set of HA sequences in Singapore. Based on the observed mutation pairing of D94N and V250A, we suspected that the desired mutation should be $\mathrm{A} \rightarrow \mathrm{V}$. Sequence examination revealed that mutations $\mathrm{A} 30 \mathrm{~V}$ and $\mathrm{N} 125 \mathrm{D}$ always occurred in pairs in the HA sequences of 2009 H1N1 in Singapore. To learn the contribution of A30V (Figure 1), this muta-
Table 2. Characteristic IS frequencies of HA proteins in 2009 H1N1, swine H1N1/H1N2, avian H1N1, and A/South Carolina/1/18 (H1N1).

\begin{tabular}{ccccc}
\hline Subtype & $\begin{array}{c}\text { 2009 } \\
\text { H1N1 }\end{array}$ & $\begin{array}{c}\text { Swine } \\
\text { H1N2/H1N1 }\end{array}$ & $\begin{array}{c}\text { Avian } \\
\text { H1N1 }\end{array}$ & $\begin{array}{c}\text { A/South } \\
\text { Carolina/1/18 } \\
\text { (H1N1) }\end{array}$ \\
\hline Frequency & $\mathrm{F}(0.295)$ & $\mathrm{F}(0.055)$ & $\mathrm{F}(0.282)$ & $\mathrm{F}(0.258)$ \\
\hline
\end{tabular}

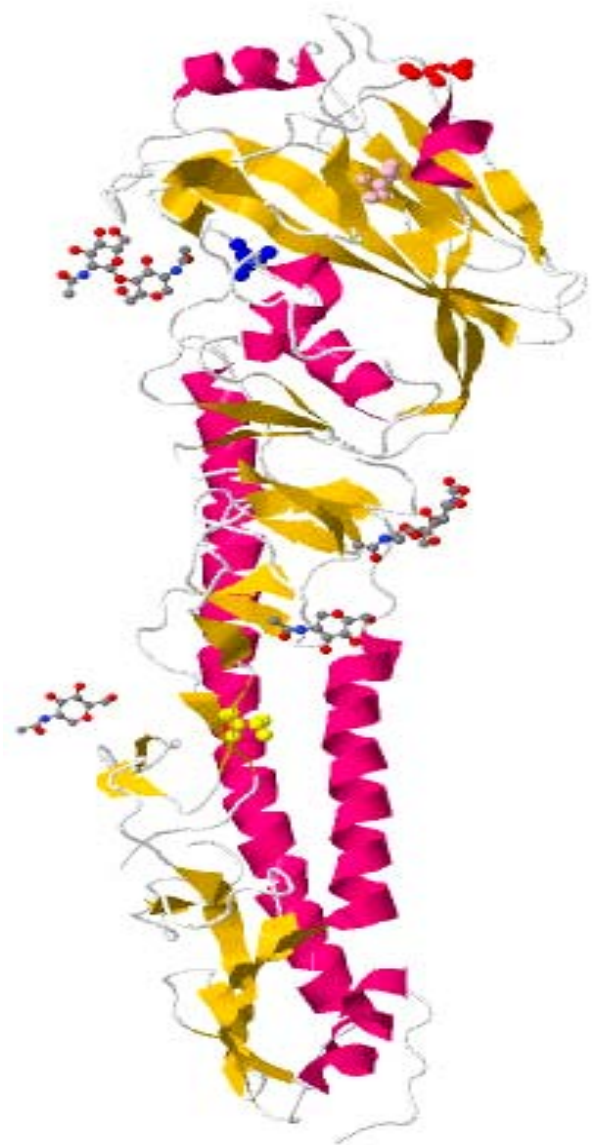

Figure 1. This plot shows in $3 \mathrm{D}$ structure the four mutations in the HA of $2009 \mathrm{H} 1 \mathrm{H} 1$ variants found in [13] and in this study. Mutation $\mathrm{A} 30 \mathrm{~V}$ is colored in yellow, D94N in blue, $\mathrm{N} 125 \mathrm{D}$ in red, and V250A in pink. (PDB code: 3AL4).

tion was applied to these HA sequences (Figure 2). Its impact was to increase IS at $\mathrm{F}(0.295)$ from 73.7483 to 77.0436 (gain $=3.2953$ ), and increase IS at $F(0.258)$ from 45.1802 to 47.3324 (gain $=2.1522$ ), so the relative gain at $\mathrm{F}(0.295)$ was 1.1431 . We could conclude that the net gain of this mutation A30V was to enhance $\mathrm{F}(0.295)$. To further examine two mutations A30V and N125D, the nine HA sequences of 2009 H1N1 in Singapore were divided into two different subsets, one with $30 \mathrm{~A}$ and $125 \mathrm{~N}(\mathrm{n}=5)$, and the other with $30 \mathrm{~V}$ and $125 \mathrm{D}(\mathrm{n}=4)$.

Figure 3 showed that a combination of $30 \mathrm{~A}$ and $125 \mathrm{~N}$ 

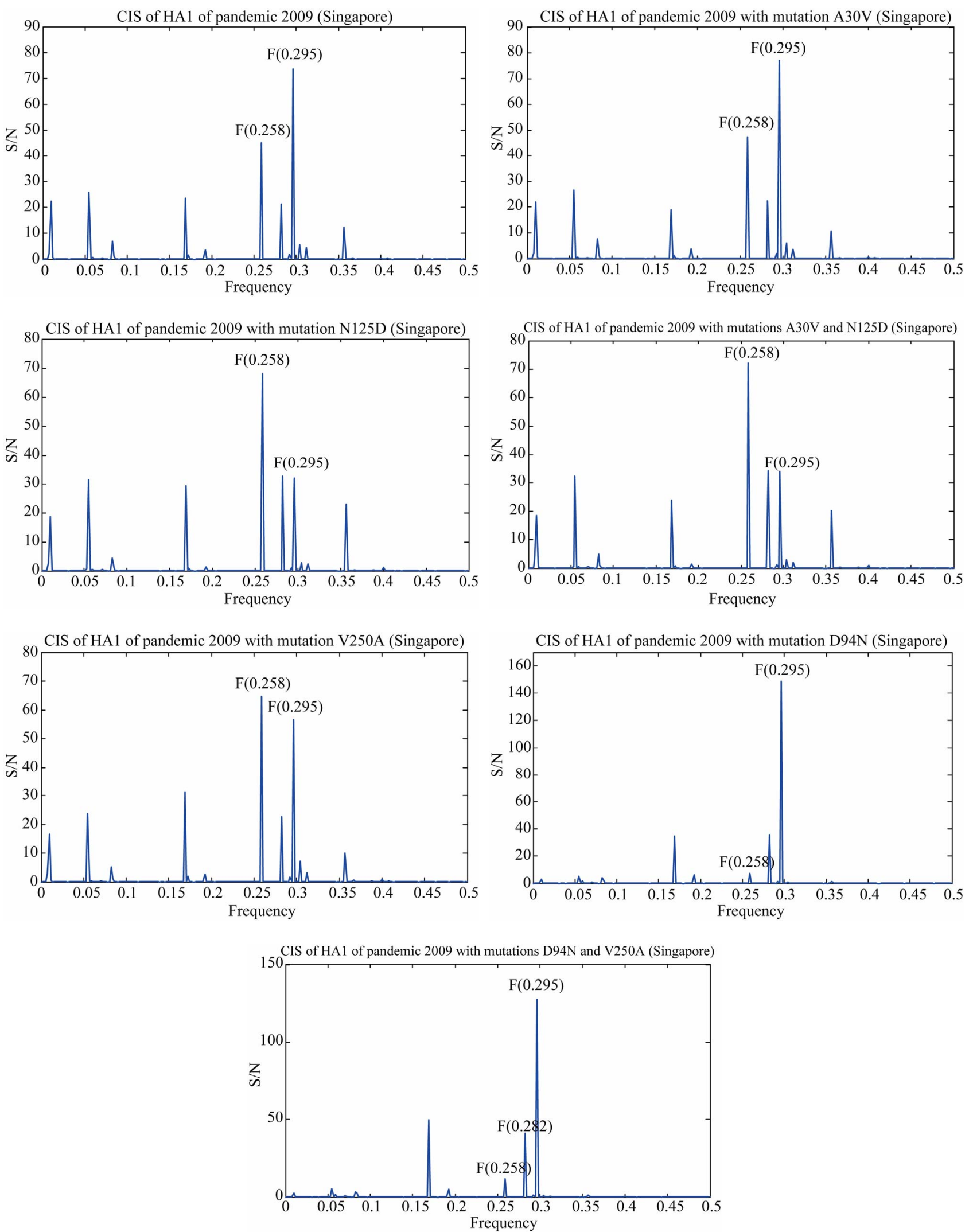

Figure 2. The impact of mutations A30V, N125D, D94N, and V250A in HA on receptor preferences of the HA protein of 2009 H1N1 in Singapore. 

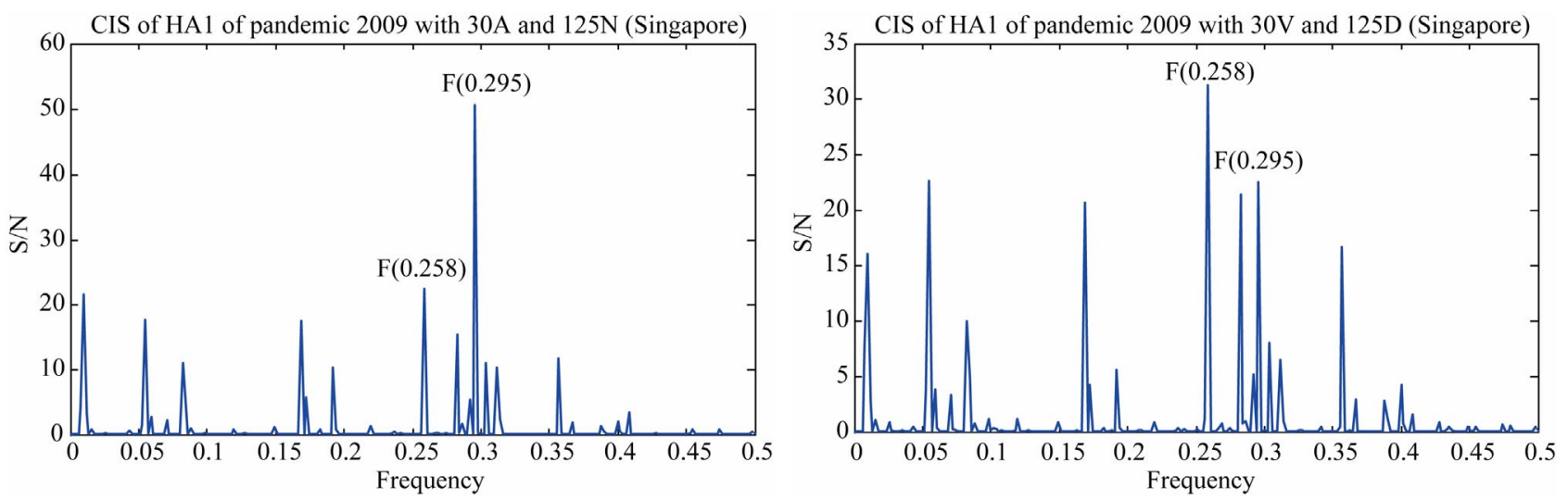

Figure 3. The impact of the amino acids at positions 30 and 125 in HA on receptor preferences of the HA protein of 2009 H1N1 in Singapore. The left plot was based on the HA sequences with $30 \mathrm{~A}$ and $125 \mathrm{~N}$, and the right plot was based on the HA sequences with $30 \mathrm{~V}$ and $125 \mathrm{D}$.

increased $\mathrm{F}(0.295)$ and decreased $\mathrm{F}(0.258)$ and $\mathrm{F}(0.282)$, while a combination of $30 \mathrm{~V}$ and $125 \mathrm{D}$ produced the opposite outcome.

An A/California/7/2009 (H1N1) like virus is part of both the northern hemisphere seasonal vaccine for 20102011 and southern hemisphere seasonal vaccine for 2011 [27], which had amino acids $94 \mathrm{D}, 125 \mathrm{~N}$, and $250 \mathrm{~V}$ in its HA protein. To investigate the reason for several vaccine breakthroughs associated with this variant virus in Oceania, we needed to compare the HA receptor preferences of $\mathrm{A} /$ California/7/2009 (H1N1) with those in Oceania. The HA sequences of 2009 H1N1 in Oceania $(n=92)$ were divided into three non-overlapping subsets according to three mutations N94D, D125N, and V250A: the first subset with amino acids 94D, 125D, and $250 \mathrm{~V}(\mathrm{n}=$ 38 ), the second with $94 \mathrm{D}, 125 \mathrm{~N}$, and $250 \mathrm{~V}(\mathrm{n}=26)$, and the third with $94 \mathrm{~N}, 125 \mathrm{D}$, and $250 \mathrm{~A}(\mathrm{n}=27)$. These sequences did not carry a mutation $\mathrm{A} 30 \mathrm{~V}$ as the HA sequences from Singapore.

It appeared that the IS of the consensus HA1 sequence with $94 \mathrm{D}, 125 \mathrm{~N}$, and $250 \mathrm{~V}$ was the most similar to that of $\mathrm{A} /$ California/7/2009 (H1N1), and the IS of the consensus HA1 sequence with $94 \mathrm{D}, 125 \mathrm{D}$, and $250 \mathrm{~V}$ was the most dissimilar to A/California/7/2009 (H1N1) (Figure 4). Therefore, it was more likely for the viruses with $94 \mathrm{D}, 125 \mathrm{D}$, and $250 \mathrm{~V}$ or $94 \mathrm{~N}, 125 \mathrm{D}$, and $250 \mathrm{~A}$ in the HA protein to cause vaccine breakthrough than the one with $94 \mathrm{D}, 125 \mathrm{~N}$, and $250 \mathrm{~V}$. The major difference between the first two variations was that the one with 94D, $125 \mathrm{D}$, and $250 \mathrm{~V}$ had $\mathrm{F}(0.258)$ as its primary frequency and the one with $94 \mathrm{~N}, 125 \mathrm{D}$, and $250 \mathrm{~A}$ had $\mathrm{F}(0.282)$ as its primary frequency.

The history of HA binding preferences of 2009 H1N1 (Table 3) implied that in the early months of its run, the virus retained the swine charactertisitcs $F(0.055)$, which disappeared in the late months of its course. On the other hand, the frequnecy $\mathrm{F}(0.258)$ of $\mathrm{A} /$ South Carolina/1/18
Table 3. Primary and secondary IS frequency of 2009 H1N1 HA by month.

\begin{tabular}{ccc}
\hline Year-Month & Primary Frequency & Secondary Frequency \\
\hline $2009-04$ & 0.295 & 0.055 \\
$2009-05$ & 0.295 & 0.258 \\
$2009-06$ & 0.295 & 0.258 \\
$2009-07$ & 0.295 & 0.258 \\
$2009-08$ & 0.295 & 0.055 \\
$2009-09$ & 0.295 & 0.258 \\
$2009-10$ & 0.295 & 0.258 \\
$2009-11$ & 0.295 & 0.258 \\
$2009-12$ & 0.295 & 0.258 \\
$2010-01$ & 0.295 & 0.258 \\
$2010-02$ & 0.295 & 0.258 \\
$2010-03$ & 0.295 & 0.258 \\
$2010-04$ & 0.295 & 0.258 \\
$2010-05$ & 0.295 & 0.258 \\
$2010-06$ & 0.295 & 0.258 \\
$2010-07$ & 0.295 & 0.258 \\
$2010-08$ & 0.295 & 0.258 \\
\hline
\end{tabular}

(H1N1) was dorminant after August 2009.

\subsection{Origin of $2009 \mathrm{H} 1 \mathrm{~N} 1$}

It is well established that the genes of $2009 \mathrm{H} 1 \mathrm{~N} 1$ are of North American and Eurasian swine origins $[1,28]$. To further learn their origins according to swine subtypes, the Hamming distances between the genes of 2009 H1N1 and those of swine H1N1 and H3N2 in North America and Europe were computed. The distance information in 
Tables 4 and 5 suggested that the HA gene of 2009 H1N1 was derived from swine H1N1 in North America, the NA gene from swine H1N1 in Europe, the M1 and M2 genes from swine H3N2 in Europe, and the NS1,
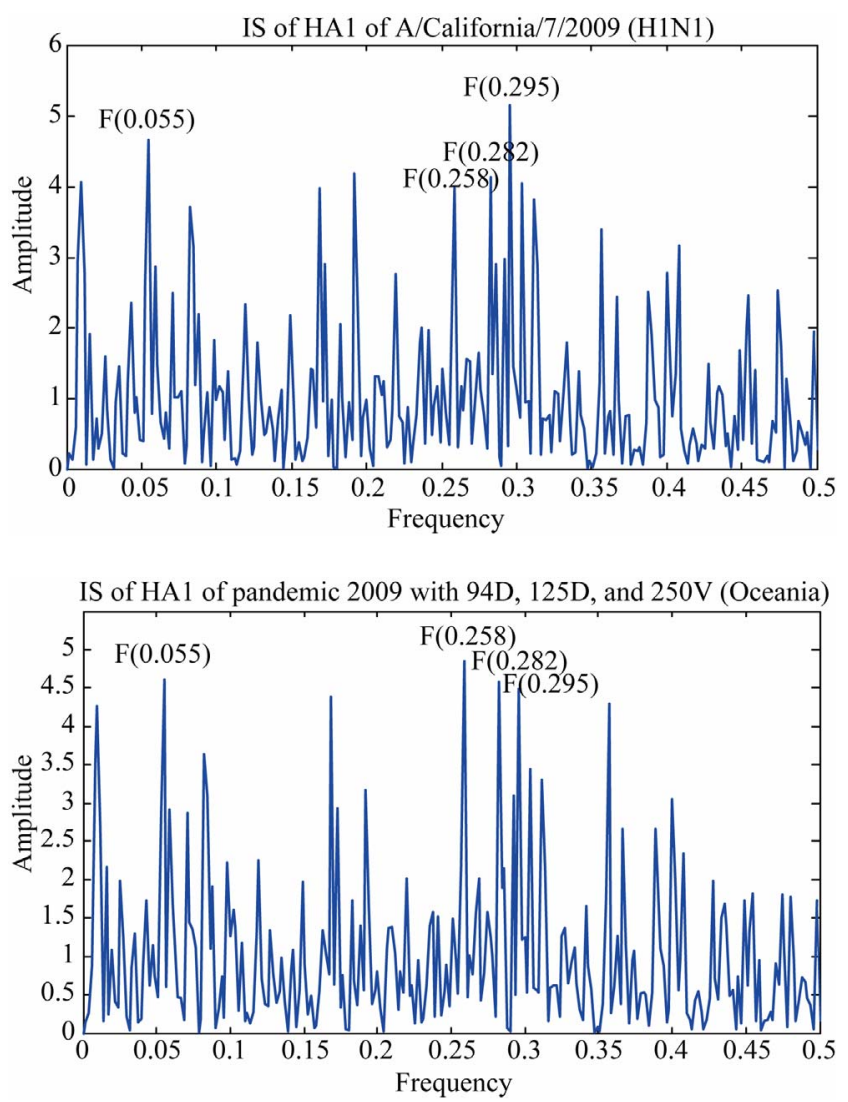

NS2, NP, PA, PB1, and PB2 genes from H3N2 in North America.

Hamming distances in Figure 5 gave further evidence that gene segments PA, PB1, and PB2 of 2009 H1N1
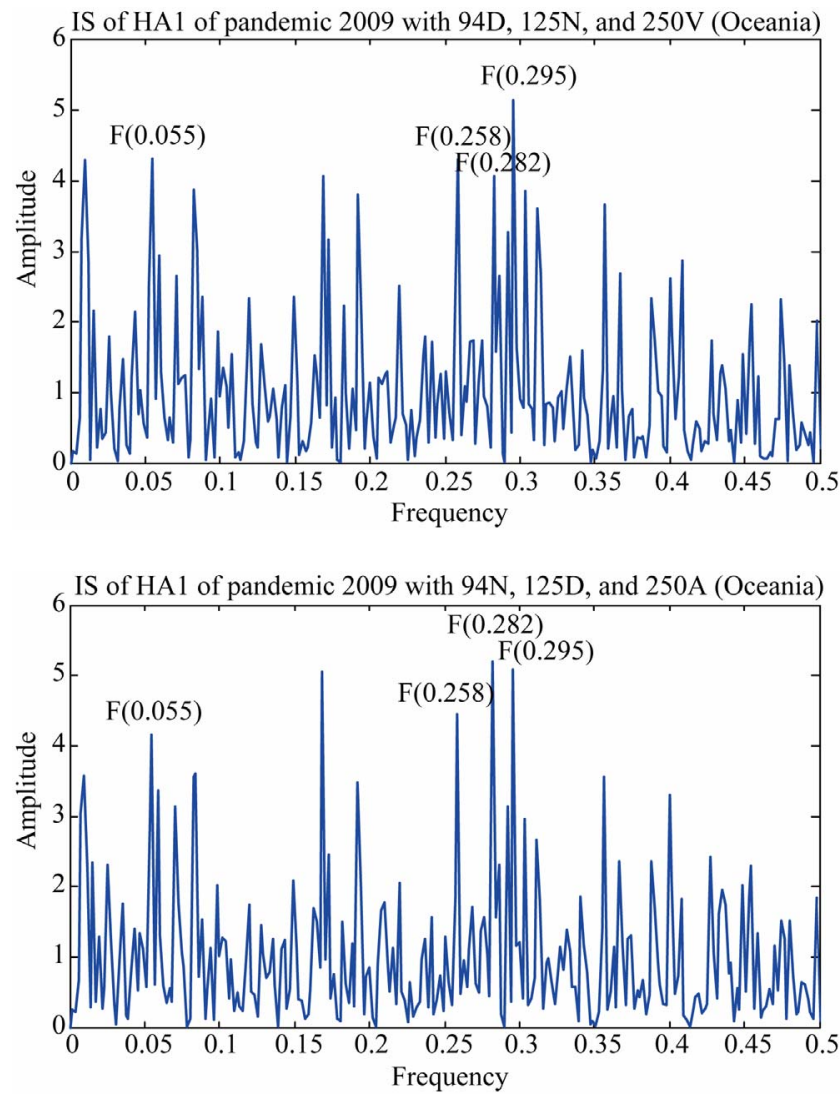

Figure 4. The IS of HA1 of A/California/7/2009 (H1N1) and IS of consensus HA1 of pandemic 2009 (Oceania). The three consensuses were taken from the HA1 sequences with specific amino acids at positions 94, 125, and 250.

Table 4. Hamming distances between consensus protein sequences of 2009 H1N1 and those of North American and Eurasian swine viruses were calculated. The minimum distance in each protein is marked with an asterisk.

\begin{tabular}{|c|c|c|c|c|c|c|c|c|c|c|}
\hline Protein & HA & NA & M1 & M2 & NS1 & NS2 & NP & PA & PB1 & PB2 \\
\hline Dist(H1N1 2009, H1N1 N_America) & $48^{*}$ & 76 & 11 & 10 & 17 & 8 & 12 & 50 & 43 & 46 \\
\hline Dist(H1N1 2009, H3N2 N_America) & & & 13 & 13 & $13 *$ & $5^{*}$ & $8^{*}$ & $14^{*}$ & $15^{*}$ & $9 *$ \\
\hline Dist(H1N1 2009, H1N1 Europe) & 108 & $24 *$ & 5 & $5^{*}$ & 42 & 15 & 32 & 31 & 26 & 25 \\
\hline Dist(H1N1 2009, H3N2 Europe) & & & $3 *$ & $5^{*}$ & 42 & 14 & 35 & 32 & 28 & 26 \\
\hline
\end{tabular}

Table 5. Hamming distances between consensus gene sequences of 2009 H1N1 and those of North American and Eurasian swine viruses were calculated. The minimum distance in each protein is marked with an asterisk.

\begin{tabular}{|c|c|c|c|c|c|c|c|c|c|c|}
\hline Gene & HA & NA & M1 & M2 & NS1 & NS2 & NP & PA & PB1 & PB2 \\
\hline Dist(H1N1 2009, H1N1 N_America) & $149^{*}$ & 267 & 91 & 21 & 48 & 21 & 92 & 373 & 423 & 358 \\
\hline Dist(H1N1 2009, H3N2 N_America) & & & 97 & 24 & $32 *$ & $13 *$ & $63^{*}$ & $88^{*}$ & $101^{*}$ & $82 *$ \\
\hline Dist(H1N1 2009, H1N1 Europe) & 431 & $81^{*}$ & 29 & 8 & 126 & 47 & 233 & 281 & 296 & 356 \\
\hline Dist(H1N1 2009, H3N2 Europe) & & & $28^{*}$ & $7 *$ & 127 & 51 & 234 & 281 & 301 & 366 \\
\hline
\end{tabular}



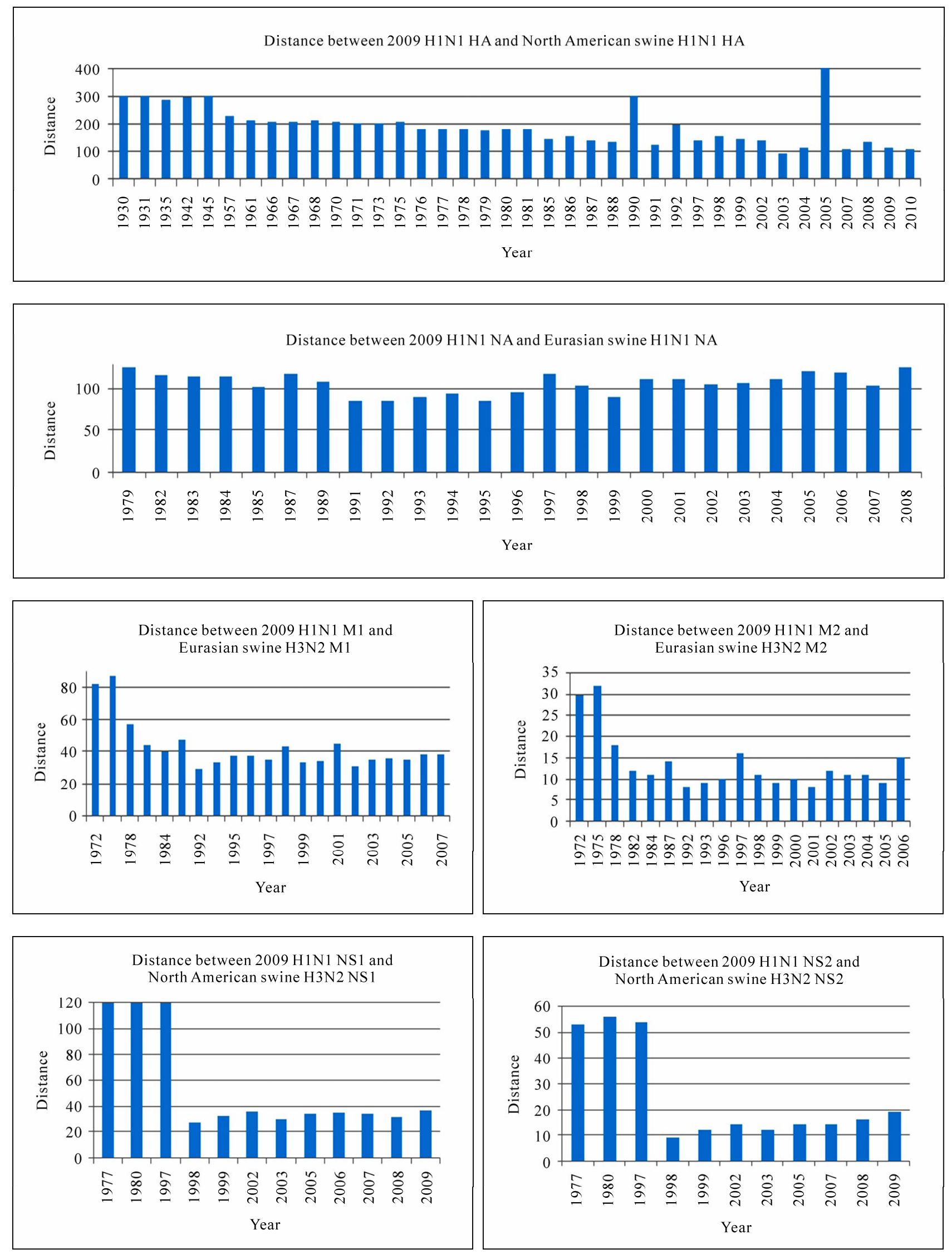

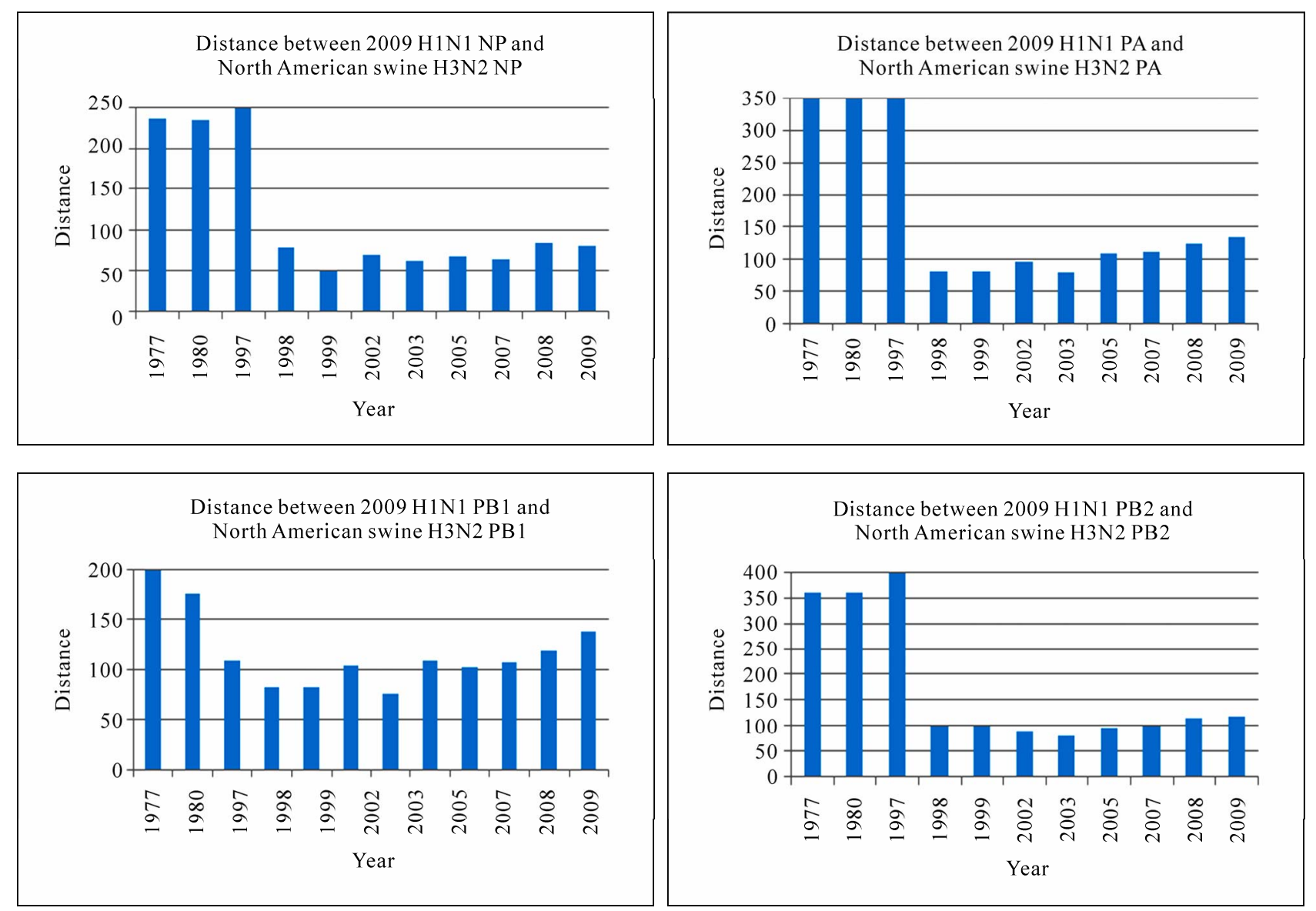

Figure 5. Hamming distances by year between consensus protein sequences of 2009 H1N1 and those of the swine viruses that were closest to 2009 H1N1 as indicated in Table 5.

were introduced to swine lineages around 1998, and gene segments NA and M of 2009 H1N1 were introduced around 1979 [1]. The findings in [1] also demonstrated that the introduction of HA, NP, and NS of 2009 H1N1 to swine lineages occurred around 1918. However, our analysis suggested that the NP and NS segments were introduced around 1998, and the HA segment around 1957, occurring much later than preciously predicted.

Codon usage bias is a unique molecular feature of many organisms including influenza viruses. This bias could influence host adaptation and the virulence of the influenza viruses because their replication relies on host cells. As the $2009 \mathrm{H} 1 \mathrm{~N} 1$ virus originated from swine lineages, it is subject to host selection pressure after cross-species transmission, which could be reflected in the codon usage of its genes.

To learn the subtle codon usage differences between $2009 \mathrm{H} 1 \mathrm{~N} 1$ and its closest swine ancestors, the condon usage patterns of their genes were displayed in Figure 6. It demonstrated that the HAs of 2009 H1N1 and North American swine H1N1 had different codon usage in Asp,
His, Gln, and Val, the NAs of 2009 H1N1 and Eurasian swine H1N1 had different codon usage in Leu, Lys, and Tyr, the Matrix genes (M1 + M2) of 2009 H1N1 and Eurasian swine H3N2 had different codon usage in Asn, Cys, Glu, Lys, and Tyr, and the genes NS1, NS2, NP, PA, $\mathrm{PB} 1$, and $\mathrm{PB} 2$ concatenated together $(\mathrm{NS} 1+\mathrm{NS} 2+\mathrm{NP}+$ PA + PB1 + PB2) of 2009 H1N1 and North American swine H3N2 had different codon usage in His. The actual differences in codon usage were summarized in Table 6, which showed that 2009 H1N1 made more use of $\mathrm{AAC}$ for Asn than swine virus, and less TAC for Tyr than swine virus. Overall, host selection pressure on human influenza viruses does not favor the use of $\mathrm{G}$ or $\mathrm{C}$ nucleotides and the use of a $\mathrm{G}$ nucleotide at the third codon position [29].

\subsection{Comparison of NP, PA, PB1 and PB2 of 2009 H1N1 with Those of Swine Lineages}

The influenza viral polymerase, composed of proteins $\mathrm{PB} 1, \mathrm{~PB} 2$, and PA, is critical in viral RNA synthesis, host adaptation, and virulence by interacting with NP. To 
GCA Gin Glu $\begin{gathered}\text { Gly } \\ \text { GAG }\end{gathered}$ Lys

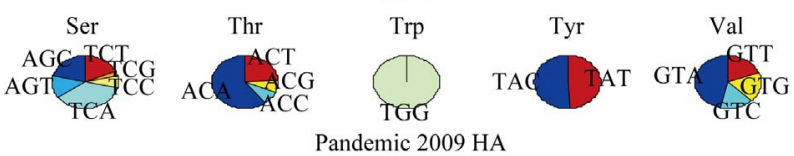

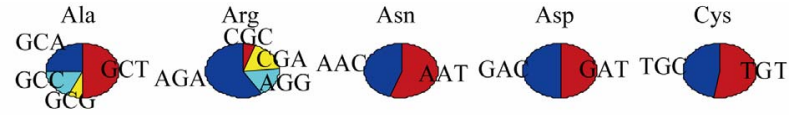
Gln Peect Ala Gln Gly ${ }_{\text {GAG }}^{\text {His }}$

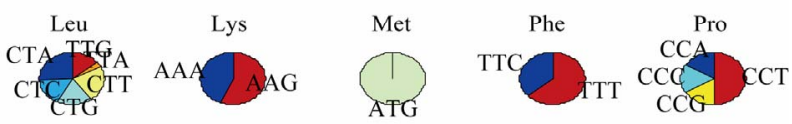

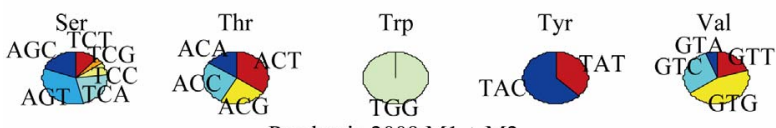
Pandemic 2009 M1 + M2

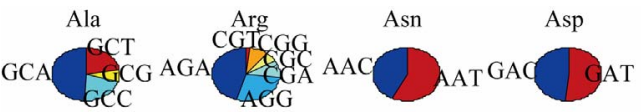
Gln $\mathrm{CAA} \mathrm{CAG}$ Glu Gly<smiles>[13CH3]CC[GeH2]</smiles>
Leu CTA TTG CTC CTA

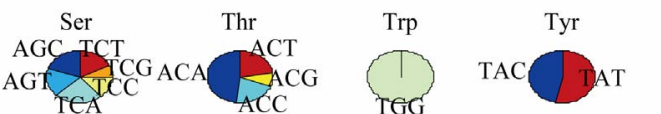
Pandemic 2009 NS1 + NS2 + NP + PA + PB1 + PB2

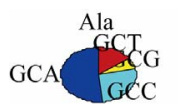
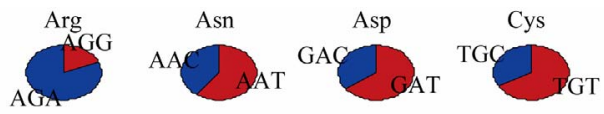

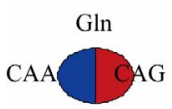<smiles>CC1(C)CCCCC1</smiles>
Gly

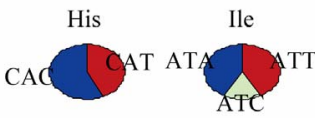

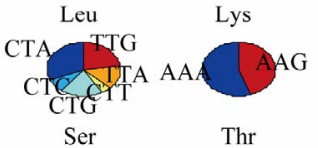

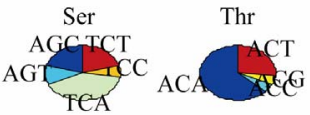<smiles>C1CCCCC1</smiles>

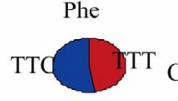

Pro Trp
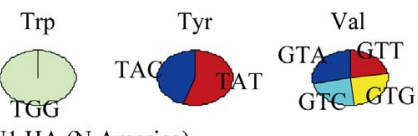

Swine H1N1 HA (N America)

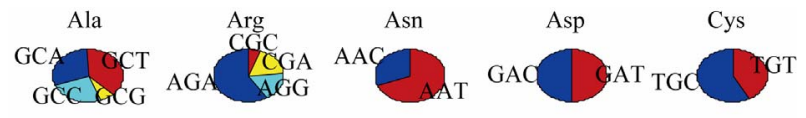

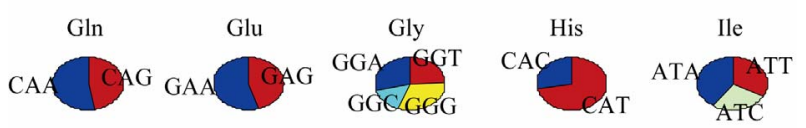

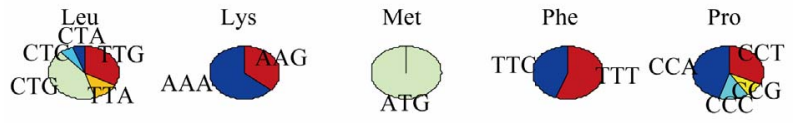

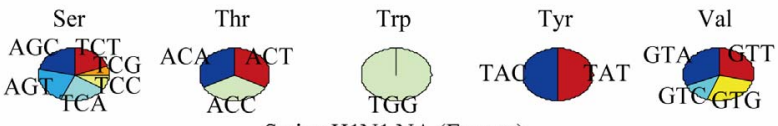
Swine H1N1 NA (Europe)

Ala GAG GAA GAG GGA Gist CAG His

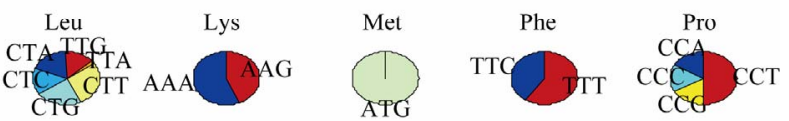
$\underset{\substack{\text { Ser } \\ \text { Swine H3N2 M1 + M2 (Europe) }}}{\text { Thr }}$

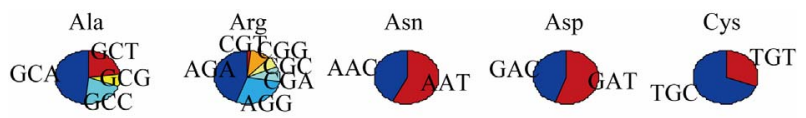

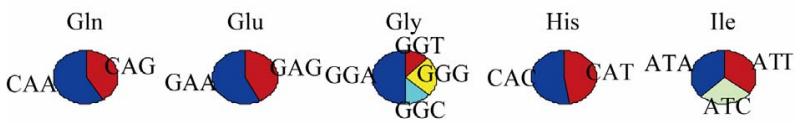
Leu

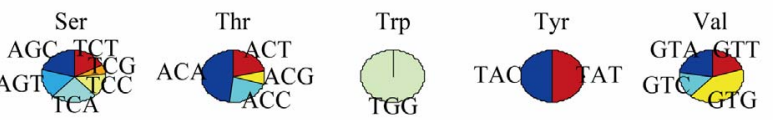
Swine H3N2 NS1 + NS2 + NP + PA + PB1 + PB2 (N America)

Figure 6. Codon bias of genes of pandemic 2009 and genes of swine viruses that were closest to those of pandemic 2009. 
Table 6. Actual codon bias of 2009 H1N1 and swine virus observed in Figure 6 .

\begin{tabular}{|c|c|c|}
\hline Gene & 2009 H1N1 & Swine virus \\
\hline HA & More GAC for Asp & Less GAC for Asp \\
\hline HA & Less CAC for His & More CAC for His \\
\hline HA & More CAG for Gln & Less CAG for Gln \\
\hline HA & Less CCG for Pro & More CCG for Pro \\
\hline HA & Less $(\mathrm{GTC}+\mathrm{GTG})$ for Val & More $(\mathrm{GTC}+\mathrm{GTG})$ for Val \\
\hline NA & Less TTC for Phe & More TTC for Phe \\
\hline NA & More AAC for Asn & Less AAC for Asn \\
\hline NA & Less CTG for Leu & More CTG for Leu \\
\hline NA & Less AAG For Lys & More AAG For Lys \\
\hline NA & Less TAC for Tyr & More TAC for Tyr \\
\hline $\mathrm{M} 1+\mathrm{M} 2$ & More AAC for Asn & Less AAC for Asn \\
\hline $\mathrm{M} 1+\mathrm{M} 2$ & More TGC for Cys & Less TGC for Cys \\
\hline $\mathrm{M} 1+\mathrm{M} 2$ & Less TAC for Tyr & More TAC for Tyr \\
\hline $\mathrm{M} 1+\mathrm{M} 2$ & Less GAG for Glu & More GAG for Glu \\
\hline $\mathrm{M} 1+\mathrm{M} 2$ & More AAG for Lys & Less AAG for Lys \\
\hline $\mathrm{NS} 1+\mathrm{NS} 2+\mathrm{NP}+\mathrm{PA}+\mathrm{PB} 1+\mathrm{PB} 2$ & More $\mathrm{CAC}$ for His & Less CAC for His \\
\hline
\end{tabular}

study the interactions between these four proteins of influenza viruses of avian, human, $2009 \mathrm{H} 1 \mathrm{~N} 1$ and swine origins, the correlated residue pairs that had a positive mutual information (MI) value were counted according to their location in the proteins [9]. It uncovered that in avian, human, $2009 \mathrm{H} 1 \mathrm{~N} 1$, and swine viruses, the inter-protein correlation from (NP, PA), (NP, PB1), (NP, PB2), (PA, PB1), (PA, PB2), (PB1, PB2) was stronger than the intra-protein correlation (NP, NP), (PA, $\mathrm{PA}),(\mathrm{PB} 1, \mathrm{~PB} 1)$ and (PB2, PB2), with (NP, NP) being the weakest. Further, the correlation pattern of 2009 H1N1 was more similar to that of avian and human influenza than to swine, in spite of the swine origin of 2009 H1N1. Using the same approach, we discovered that the interaction pattern of the four proteins of North American swine H1N1 was most similar to that of 2009 H1N1, although the sequence identity of the four proteins of North American swine H3N2 was most similar to that of 2009 H1N1 (Figure 7). Our findings reinforced the concept that sequence identity is only one of the many factors to measure the similarity of two influenza viruses.

Many of the classical markers for adaptation of avian or swine viruses to human hosts do not exist in 2009 H1N1, implying that other previously unrecognized molecular determinants are accountable for its capability to infect humans. The study in [4,5] discovered novel host markers in the proteins of $2009 \mathrm{H} 1 \mathrm{~N} 1$ that were not present in the traditional host markers. These novel markers were identified by the significant residue positions that could separate 2009 H1N1 from human viruses subtracted by the characteristic positions in avian and swine viruses, which were marked as (a) for avian and (s) for swine positions in Tables 7-10. To further examine the important positions in NP, PA, PB1, and PB2 of 2009 H1N1, we compared them to those of swine lineages in North America and Europe, and avian, human, swine (general) viruses (Tables 7-10).

There were several important positions in the NP, PA, PB1, and PB2 of avian, human, swine (general), swine H1N1 in North America and in Europe that shared the same amino acid but 2009 H1N1 had a different amino acid at the same positions, reflecting the uniqueness of this novel virus. These positions were 53 and 316 in NP, $186,204,213,275,336$, and 626 in PA, 12, 175, 216, 298, 364, 386, and 728 in PB1, and 54, 684 in PB2. At positions 353, 377, 444, 498 in NP, 362, 388, 407 in PA, $179,339,361,486,584,638,741$ in PB1, and 65, 147, $225,590,591,645$ in PB2, swine H3N2 in North America and 2009 H1N1 shared the same amino acid, but differed from other viruses (Tables 7-10). The amino acid (serine) at position 186 in PA of 2009 H1N1 was found to be necessary for its compatibility with PB2 and PB1 subunits [30], and the amino acids at positions 590 and 591 in PB2 were the SR polymorphism uncovered in [31].

The PB2 of 2009 H1N1 does not carry the human signature $627 \mathrm{~K}$, yet this virus replicates in humans and 

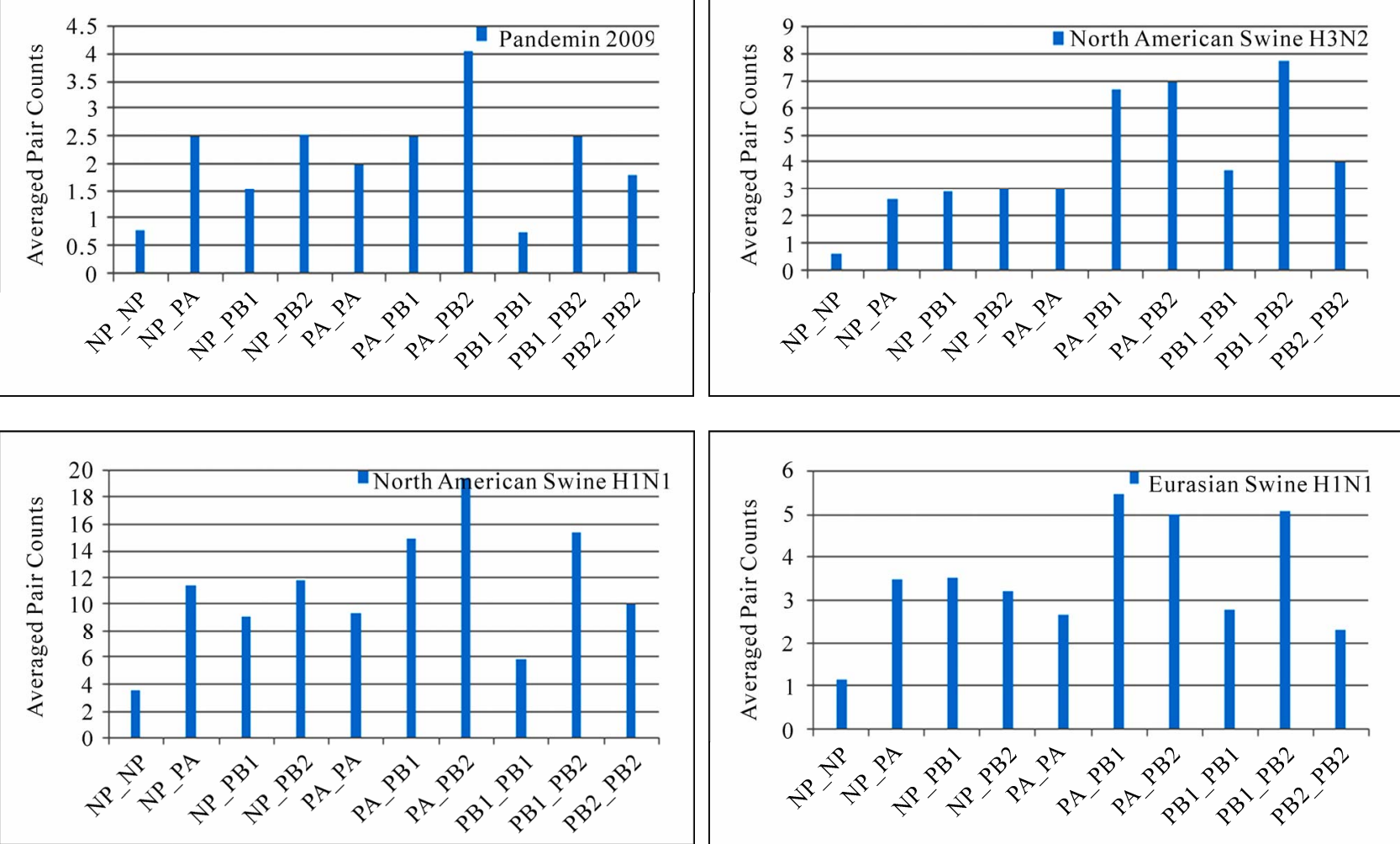

Figure 7. Averaged correlated pair counts in each individual protein and between proteins of $2009 \mathrm{H} 1 \mathrm{~N} 1$ and swine viruses.

Table 7. This table contains the consensus amino acids at the sites in NP that have high importance in separating 2009 H1N1 from human viruses [4,5]. The novel host sites in this protein are the positions without a 'a' (for avian) or a 's' (for swine) or both.

\begin{tabular}{|c|c|c|c|c|c|c|c|c|c|c|}
\hline Position & 21 & $31(\mathrm{a}, \mathrm{s})$ & 53 & 119 & $189(\mathrm{~s})$ & 190 & 217(a) & $289(\mathrm{~s})$ & $313(a, s)$ & 316 \\
\hline Avian & $\mathrm{N}$ & $\mathrm{R}$ & $\mathrm{E}$ & I & M & V & I & $\mathrm{Y}$ & $\mathrm{F}$ & I \\
\hline Human & $\mathrm{N}$ & $\mathrm{K}$ & $\mathrm{E}$ & I & M & $\mathrm{V}$ & $\mathrm{S}$ & $\mathrm{Y}$ & Y & I \\
\hline 2009 H1N1 & $\mathrm{D}$ & $\mathrm{R}$ & $\mathrm{D}$ & $\mathrm{V}$ & I & A & V & $\mathrm{H}$ & V & M \\
\hline Swine & $\mathrm{D}$ & $\mathrm{R}$ & $\mathrm{E}$ & $\mathrm{V}$ & I & A & I & $\mathrm{H}$ & $\mathrm{F}$ & I \\
\hline Swine H1N1(North America) & $\mathrm{D}$ & $\mathrm{R}$ & $\mathrm{E}$ & $\mathrm{V}$ & I & A & I & $\mathrm{H}$ & $\mathrm{F}$ & I \\
\hline Swine H1N1(Europe) & $\mathrm{N}$ & $\mathrm{R}$ & E & I & M & V & I & $\mathrm{Y}$ & $\mathrm{F}$ & I \\
\hline Swine H3N2 (North America) & $\mathrm{D}$ & $\mathrm{R}$ & $\mathrm{E}$ & V & I & A & I & $\mathrm{H}$ & $\mathrm{F}$ & I \\
\hline Swine H3N2 (Europe) & $\mathrm{N}$ & $\mathrm{R}$ & $\mathrm{E}$ & I & M & V & I & $\mathrm{Y}$ & F & I \\
\hline Position & $350(\mathrm{~s})$ & 353 & 371 & 373(a) & 377 & $430(s)$ & 433 & 444 & $456(s)$ & 498 \\
\hline Avian & $\mathrm{T}$ & $\mathrm{V}$ & M & $\mathrm{T}$ & $\mathrm{S}$ & $\mathrm{T}$ & $\mathrm{T}$ & I & $\mathrm{V}$ & $\mathrm{N}$ \\
\hline Human & $\mathrm{T}$ & $\mathrm{S}$ & M & A & $\mathrm{S}$ & $\mathrm{T}$ & $\mathrm{T}$ & I & V & $\mathrm{N}$ \\
\hline 2009 H1N1 & K & I & $\mathrm{V}$ & $\mathrm{T}$ & $\mathrm{N}$ & $\mathrm{S}$ & $\mathrm{N}$ & $\mathrm{V}$ & $\mathrm{L}$ & $\mathrm{S}$ \\
\hline Swine & K & $\mathrm{V}$ & $\mathrm{V}$ & A & $\mathrm{S}$ & $\mathrm{S}$ & $\mathrm{N}$ & I & $\mathrm{L}$ & $\mathrm{N}$ \\
\hline Swine H1N1(North America) & K & $\mathrm{V}$ & $\mathrm{V}$ & A & $\mathrm{S}$ & I & $\mathrm{N}$ & I & $\mathrm{L}$ & $\mathrm{N}$ \\
\hline Swine H1N1(Europe) & $\mathrm{T}$ & $\mathrm{V}$ & M & $\mathrm{T}$ & I & $\mathrm{T}$ & $\mathrm{T}$ & I & V & $\mathrm{N}$ \\
\hline Swine H3N2 (North America) & K & I & $\mathrm{V}$ & A & $\mathrm{N}$ & $\mathrm{S}$ & $\mathrm{N}$ & $\mathrm{V}$ & $\mathrm{L}$ & $\mathrm{S}$ \\
\hline Swine H3N2 (Europe) & $\mathrm{T}$ & $\mathrm{V}$ & M & $\mathrm{T}$ & I & $\mathrm{T}$ & $\mathrm{T}$ & I & $\mathrm{V}$ & $\mathrm{N}$ \\
\hline
\end{tabular}


Table 8. This table contains the consensus amino acids at the sites in PA that have high importance in separating 2009 H1N1 from human viruses $[4,5]$. The novel host sites in this protein are the positions without a 'a' (for avian) or a 's' (for swine) or both.

\begin{tabular}{|c|c|c|c|c|c|c|c|c|c|c|c|}
\hline Position & $28(\mathrm{a}, \mathrm{s})$ & $55(\mathrm{a})$ & 85 & $100(a, s)$ & 186 & 204 & 213 & 256 & 262 & 275 & 277 \\
\hline Avian & $\mathrm{P}$ & $\mathrm{D}$ & $\mathrm{T}$ & $\mathrm{V}$ & G & $\mathrm{R}$ & $\mathrm{R}$ & $\mathrm{R}$ & $\mathrm{K}$ & $\mathrm{P}$ & $\mathrm{S}$ \\
\hline Human & $\mathrm{L}$ & $\mathrm{N}$ & $\mathrm{T}$ & A & G & $\mathrm{R}$ & $\mathrm{R}$ & $\mathrm{R}$ & $\mathrm{K}$ & $P$ & $\mathrm{~S}$ \\
\hline $2009 \mathrm{H} 1 \mathrm{~N} 1$ & $\mathrm{P}$ & $\mathrm{D}$ & I & $\mathrm{V}$ & $\mathrm{S}$ & $\mathrm{K}$ & $\mathrm{K}$ & $\mathrm{K}$ & $\mathrm{R}$ & $\mathrm{L}$ & $\mathrm{H}$ \\
\hline Swine & $P$ & $\mathrm{D}$ & $\mathrm{T}$ & $\mathrm{V}$ & G & $\mathrm{R}$ & $\mathrm{R}$ & $\mathrm{R}$ & $\mathrm{K}$ & $\mathrm{P}$ & $\mathrm{S}$ \\
\hline Swine H1N1(North America) & $\mathrm{P}$ & $\mathrm{N}$ & $\mathrm{N}$ & $\mathrm{V}$ & G & $\mathrm{R}$ & $\mathrm{R}$ & $\mathrm{R}$ & $\mathrm{K}$ & $\mathrm{P}$ & $\mathrm{F}$ \\
\hline Swine H1N1(Europe) & $\mathrm{P}$ & $\mathrm{D}$ & $\mathrm{T}$ & $\mathrm{V}$ & G & $\mathrm{R}$ & $\mathrm{R}$ & $\mathrm{R}$ & $\mathrm{R}$ & $\mathrm{P}$ & $\mathrm{S}$ \\
\hline Swine H3N2 (North America) & $\mathrm{S}$ & $\mathrm{D}$ & $\mathrm{T}$ & $\mathrm{V}$ & G & $\mathrm{R}$ & $\mathrm{R}$ & Q & $\mathrm{K}$ & $P$ & $\mathrm{~S}$ \\
\hline Swine H3N2 (Europe) & $\mathrm{P}$ & $\mathrm{D}$ & $\mathrm{T}$ & $\mathrm{V}$ & G & $\mathrm{R}$ & $\mathrm{R}$ & $\mathrm{R}$ & $\mathrm{R}$ & $P$ & $\mathrm{~F}$ \\
\hline Position & 336 & $337(\mathrm{a}, \mathrm{s})$ & $356(a)$ & 362 & 388 & $400(\mathrm{a}, \mathrm{s})$ & 404(a,s) & 407 & $552(\mathrm{a}, \mathrm{s})$ & 626 & \\
\hline Avian & $\mathrm{L}$ & A & $\mathrm{K}$ & $\mathrm{K}$ & $\mathrm{S}$ & $\mathrm{S}$ & A & I & $\mathrm{T}$ & K & \\
\hline Human & $\mathrm{L}$ & $\mathrm{S}$ & $\mathrm{R}$ & $\mathrm{K}$ & $\mathrm{S}$ & $\mathrm{L}$ & $\mathrm{S}$ & I & $\mathrm{S}$ & $\mathrm{K}$ & \\
\hline $2009 \mathrm{H} 1 \mathrm{~N} 1$ & M & A & $\mathrm{R}$ & $\mathrm{R}$ & G & $P$ & A & $\mathrm{V}$ & $\mathrm{T}$ & $\mathrm{R}$ & \\
\hline Swine & $\mathrm{L}$ & A & $\mathrm{K}$ & $\mathrm{K}$ & $\mathrm{S}$ & $\mathrm{P}$ & A & I & $\mathrm{T}$ & $\mathrm{K}$ & \\
\hline Swine H1N1(North America) & $\mathrm{L}$ & A & $\mathrm{R}$ & $\mathrm{K}$ & $\mathrm{S}$ & $\mathrm{F}$ & A & I & $\mathrm{T}$ & $\mathrm{K}$ & \\
\hline Swine H1N1(Europe) & $\mathrm{L}$ & A & $\mathrm{K}$ & $\mathrm{K}$ & G & M & A & I & $\mathrm{T}$ & $\mathrm{K}$ & \\
\hline Swine H3N2 (North America) & $\mathrm{L}$ & A & $\mathrm{K}$ & $\mathrm{R}$ & G & $P$ & A & $\mathrm{V}$ & $\mathrm{T}$ & $\mathrm{K}$ & \\
\hline Swine H3N2 (Europe) & $\mathrm{L}$ & A & $\mathrm{K}$ & $\mathrm{K}$ & G & M & A & I & $\mathrm{T}$ & $\mathrm{K}$ & \\
\hline
\end{tabular}

Table 9. This table contains the consensus amino acids at the sites in PB1 that have high importance in separating 2009 H1N1 from human viruses [4,5]. The novel host sites in this protein are the positions without a 'a' (for avian) or a 's' (for swine) or both.

\begin{tabular}{|c|c|c|c|c|c|c|c|c|c|c|}
\hline Position & 12 & 175 & 179 & 216 & 298 & $327(\mathrm{a}, \mathrm{s})$ & $339(\mathrm{~s})$ & $361(a, s)$ & 364 & $386(s)$ \\
\hline Avian & $\mathrm{V}$ & $\mathrm{D}$ & M & $\mathrm{S}$ & $\mathrm{L}$ & $\mathrm{R}$ & I & S & $\mathrm{L}$ & $\mathrm{R}$ \\
\hline Human & $\mathrm{V}$ & $\mathrm{D}$ & M & $\mathrm{S}$ & $\mathrm{L}$ & $\mathrm{K}$ & I & S & $\mathrm{L}$ & $\mathrm{R}$ \\
\hline $2009 \mathrm{H} 1 \mathrm{~N} 1$ & I & $\mathrm{N}$ & I & G & I & $\mathrm{R}$ & M & $\mathrm{R}$ & I & K \\
\hline Swine & $\mathrm{V}$ & $\mathrm{D}$ & M & S & $\mathrm{L}$ & $\mathrm{R}$ & I & $\mathrm{N}$ & $\mathrm{L}$ & $\mathrm{R}$ \\
\hline Swine H1N1(North America) & $\mathrm{V}$ & $\mathrm{D}$ & M & $\mathrm{S}$ & $\mathrm{L}$ & $\mathrm{R}$ & V & $\mathrm{N}$ & $\mathrm{L}$ & $\mathrm{R}$ \\
\hline Swine H1N1(Europe) & $\mathrm{V}$ & $\mathrm{D}$ & M & $\mathrm{S}$ & $\mathrm{L}$ & $\mathrm{R}$ & I & S & $\mathrm{L}$ & $\mathrm{R}$ \\
\hline Swine H3N2 (North America) & $\mathrm{V}$ & $\mathrm{D}$ & I & $\mathrm{S}$ & $\mathrm{L}$ & $\mathrm{R}$ & M & $\mathrm{R}$ & $\mathrm{L}$ & $\mathrm{R}$ \\
\hline Swine H3N2 ((Europe) & $\mathrm{V}$ & $\mathrm{D}$ & M & $\mathrm{S}$ & $\mathrm{L}$ & $\mathrm{R}$ & I & $\mathrm{S}$ & $\mathrm{L}$ & $\mathrm{R}$ \\
\hline Position & 435 & 486 & $517(\mathrm{~s})$ & $584(\mathrm{a}, \mathrm{s})$ & 587 & 618 & $638(\mathrm{~s})$ & 728 & $741(\mathrm{a}, \mathrm{s})$ & \\
\hline Avian & $\mathrm{T}$ & $\mathrm{R}$ & I & $\mathrm{R}$ & A & $\mathrm{E}$ & $\mathrm{E}$ & I & A & \\
\hline Human & $\mathrm{T}$ & $\mathrm{R}$ & I & $\mathrm{R}$ & A & $\mathrm{E}$ & $\mathrm{E}$ & I & A & \\
\hline 2009 H1N1 & I & K & V & Q & V & $\mathrm{D}$ & $\mathrm{D}$ & V & S & \\
\hline Swine & $\mathrm{T}$ & $\mathrm{R}$ & I & $\mathrm{R}$ & A & $\mathrm{E}$ & $\mathrm{E}$ & I & A & \\
\hline Swine H1N1(North America) & A & $\mathrm{R}$ & I & $\mathrm{R}$ & A & K & $\mathrm{E}$ & I & A & \\
\hline Swine H1N1(Europe) & $\mathrm{T}$ & $\mathrm{R}$ & $\mathrm{V}$ & $\mathrm{H}$ & $\mathrm{T}$ & $\mathrm{E}$ & $\mathrm{E}$ & I & A & \\
\hline Swine H3N2 (North America) & $\mathrm{T}$ & K & I & Q & A & $\mathrm{E}$ & $\mathrm{D}$ & I & S & \\
\hline Swine H3N2 ((Europe) & $\mathrm{T}$ & $\mathrm{R}$ & $\mathrm{V}$ & $\mathrm{H}$ & A & E & $\mathrm{E}$ & I & A & \\
\hline
\end{tabular}


Table 10. This table contains the consensus amino acids at the sites in PB2 that have high importance in separating 2009 H1N1 from human viruses $[4,5]$. The novel host sites in this protein are the positions without a 'a' (for avian) or a 's' (for swine) or both.

\begin{tabular}{|c|c|c|c|c|c|c|c|c|c|}
\hline Position & $9(a)$ & 54 & $64(\mathrm{a}, \mathrm{s})$ & $65(\mathrm{~s})$ & $81(\mathrm{a}, \mathrm{s})$ & $105(\mathrm{a}, \mathrm{s})$ & 147 & $184(s)$ & $199(\mathrm{a}, \mathrm{s})$ \\
\hline Avian & $\mathrm{D}$ & $\mathrm{K}$ & M & $\mathrm{E}$ & $\mathrm{T}$ & $\mathrm{T}$ & I & $\mathrm{T}$ & A \\
\hline Human & $\mathrm{N}$ & $\mathrm{K}$ & $\mathrm{T}$ & $\mathrm{E}$ & M & $\mathrm{V}$ & I & $\mathrm{T}$ & $\mathrm{S}$ \\
\hline 2009 H1N1 & $\mathrm{D}$ & $\mathrm{R}$ & M & $\mathrm{D}$ & $\mathrm{T}$ & $\mathrm{T}$ & $\mathrm{T}$ & A & A \\
\hline Swine & $\mathrm{D}$ & $\mathrm{K}$ & M & $\mathrm{E}$ & $\mathrm{T}$ & $\mathrm{T}$ & I & $\mathrm{T}$ & A \\
\hline Swine H1N1(North America) & $\mathrm{N}$ & $\mathrm{K}$ & I & $\mathrm{E}$ & $\mathrm{T}$ & A & I & M & S \\
\hline Swine H1N1(Europe) & $\mathrm{D}$ & $\mathrm{K}$ & M & $\mathrm{E}$ & $\mathrm{T}$ & $\mathrm{T}$ & I & $\mathrm{T}$ & A \\
\hline Swine H3N2 (North America) & $\mathrm{D}$ & $\mathrm{K}$ & M & $\mathrm{D}$ & $\mathrm{T}$ & $\mathrm{T}$ & $\mathrm{T}$ & $\mathrm{T}$ & A \\
\hline Swine H3N2 ((Europe) & $\mathrm{D}$ & $\mathrm{K}$ & M & $\mathrm{E}$ & $\mathrm{T}$ & $\mathrm{T}$ & I & $\mathrm{T}$ & A \\
\hline Position & 225 & $292(a, s)$ & 315 & $340(s)$ & 453 & $475(a)$ & 559 & $567(\mathrm{a}, \mathrm{s})$ & $588(\mathrm{a}, \mathrm{s})$ \\
\hline Avian & S & I & M & $\mathrm{R}$ & $\mathrm{P}$ & $\mathrm{L}$ & $\mathrm{T}$ & $\mathrm{D}$ & A \\
\hline Human & S & $\mathrm{T}$ & M & $\mathrm{R}$ & $\mathrm{H}$ & M & $\mathrm{T}$ & $\mathrm{N}$ & I \\
\hline 2009 H1N1 & G & $\mathrm{V}$ & I & $\mathrm{K}$ & S & $\mathrm{L}$ & I & $\mathrm{D}$ & $\mathrm{T}$ \\
\hline Swine & S & I & M & $\mathrm{R}$ & $\mathrm{P}$ & $\mathrm{L}$ & $\mathrm{T}$ & $\mathrm{D}$ & A \\
\hline Swine H1N1(North America) & S & $\mathrm{T}$ & $\mathrm{V}$ & M & $\mathrm{K}$ & $\mathrm{R}$ & I & S & I \\
\hline Swine H1N1(Europe) & $\mathrm{S}$ & $\mathrm{T}$ & I & M & $\mathrm{K}$ & $\mathrm{R}$ & I & $P$ & $\mathrm{~V}$ \\
\hline Swine H3N2 (North America) & G & A & I & M & $\mathrm{K}$ & $\mathrm{K}$ & I & $\mathrm{P}$ & I \\
\hline Swine H3N2 ((Europe) & S & I & I & M & $\mathrm{K}$ & $\mathrm{R}$ & I & $P$ & $\mathrm{~V}$ \\
\hline Position & 590 & $591(\mathrm{~s})$ & $613(a, s)$ & $627(\mathrm{a}, \mathrm{s})$ & 645 & $661(a, s)$ & 667 & $674(a, s)$ & 684(a) \\
\hline Avian & G & Q & $\mathrm{V}$ & $\mathrm{E}$ & M & A & $\mathrm{V}$ & A & A \\
\hline Human & G & Q & $\mathrm{T}$ & $\mathrm{K}$ & M & $\mathrm{T}$ & I & $\mathrm{T}$ & A \\
\hline 2009 H1N1 & S & $\mathrm{R}$ & $\mathrm{V}$ & $\mathrm{E}$ & $\mathrm{L}$ & A & $\mathrm{V}$ & A & S \\
\hline Swine & G & Q & $\mathrm{V}$ & $\mathrm{E}$ & M & A & $\mathrm{V}$ & A & A \\
\hline Swine H1N1(North America) & G & Q & $\mathrm{V}$ & $\mathrm{K}$ & M & $\mathrm{S}$ & A & $\mathrm{N}$ & A \\
\hline Swine H1N1(Europe) & G & $\mathrm{Q}$ & A & $\mathrm{E}$ & M & A & A & $\mathrm{T}$ & A \\
\hline Swine H3N2 (North America) & S & $\mathrm{R}$ & $\mathrm{V}$ & $\mathrm{E}$ & $\mathrm{L}$ & A & A & $\mathrm{T}$ & A \\
\hline Swine H3N2 ((Europe) & $\mathrm{G}$ & Q & $\mathrm{A}$ & E & M & A & A & $\mathrm{T}$ & A \\
\hline
\end{tabular}

are efficiently transmitted in humans. The SR polymorphism was recently identified in [31] as a mechanism for 2009 H1N1 to partially overcome the lack of K627 by enhancing polymerase activity. However, as early as in 2002, the SR occurred in the PB2 of swine H3N2 in North America (A/swine/Iowa/H02AS8/2002(H3N2)), but none was found in the PB2 of Eurasian swine H1N1 and H3N2. Even though the majority of the PB2 proteins of North American swine H1N1 had GQ, some of them had SR, as early as in 2002 (A/swine/Iowa/ H02NJ56371/2002(H1N1)), and GR in 2008 (A/swine/ Nebraska/02013/2008(H1N1)). Typically, GQ was coupled with $627 \mathrm{~K}$, though SR and GR were tied with $627 \mathrm{E}$.

\section{CONCLUSIONS}

A genetic variant of 2009 H1N1 recently emerged as a predominant virus in Australia, New Zealand, and Singapore during the winter season of 2010 in the southern hemisphere. Our ISM analysis on the three mutations D94N, N125D, and V250A found in [13,32] suggested that the biological reason for the mutation pairing of D94N, and V250A was to keep the human type receptor as its primary binding preference so the virus could replicate in humans efficiently. Mutation V250A compensated for D94N. Based on this interpretation, we searched for and uncovered a new mutation $\mathrm{A} 30 \mathrm{~V}$ that 
compensated for N125D. We quantitatively investigated how mutations A30V, D94N, N125D, and V250A in the HA protein of this variant may affect its HA receptor binding affinity. In summary, mutation A30V increased IS frequency $F(0.295)$ and decreased $F(0.258)$, while V250A did the opposite. At the same time, mutation D94N increased $F(0.295)$ and decreased $F(0.258)$ and $\mathrm{F}(0.282)$, whereas $\mathrm{N} 125 \mathrm{D}$ functioned the opposite. When combined together, D94N and V250A increased $F(0.295)$ and $F(0.282)$ and decreased $F(0.258)$, but A30V and N125D produced the opposite. Our ISM results also implied that the recent vaccine breakthroughs were partially caused by the alteration of HA receptor binding specificity resulted from these HA mutations.

As the second task of our investigation, we revisited the origin of $2009 \mathrm{H} 1 \mathrm{~N} 1$ to refine our understanding of this important issue. Our findings illustrated that the HA gene of $2009 \mathrm{H} 1 \mathrm{~N} 1$ came from that of swine H1N1 in North America, the NA gene from Eurasian swine H1N1, the M1 and M2 genes from Eurasian swine H3N2, and the NS1, NS2, NP, PA, PB1, and PB2 genes from swine H3N2 in North America. In addition, our analysis provided the timeline for the occurrence of genes of swine lineages most similar to those of $2009 \mathrm{H} 1 \mathrm{~N} 1$. Although the four proteins NP, PA, PB1, and PB2 of 2009 H1N1 were closest to those of North American swine H3N2 in sequence identity, their interaction patterns were closest to those of swine H1N1 in North America.

\section{ACKNOWLEDGEMENTS}

We thank Houghton College for its financial support.

\section{REFERENCES}

[1] Garten, R.J., Davis, C.T., Russell, C.A., Shu, B., Lindstrom, S., Balish, A., et al. (2009) Antigenic and genetic characteristics of swine-origin 2009 A(H1N1) influenza viruses circulating in humans. Science, 325, 197-201. doi: $10.1126 /$ science. 1176225

[2] Hu, W. (2009) Analysis of correlated mutations, stalk motifs, and phylogenetic relationship of the 2009 influenza A virus neuraminidase sequences. Journal of Biomedical Science and Engineering, 2, 550-558. doi:10.4236/jbise. 2009.27080

[3] $\mathrm{Hu}, \mathrm{W}$. (2010) The Interaction between the $2009 \mathrm{H} 1 \mathrm{~N} 1$ influenza A hemagglutinin and neuraminidase: Mutations, co-mutations, and the NA stalk motifs. Journal of Biomedical Science and Engineering, 3, 1-12.

[4] Hu, W. (2010) Novel host markers in the 2009 pandemic H1N1 influenza A virus. Journal of Biomedical Science and Engineering, 3, 584-601. doi:10.4236/jbise.2010.36081

[5] Hu, W. (2010) Nucleotide host markers in the influenza A viruses. Journal of Biomedical Science and Engineering, 3, 684-699. doi:10.4236/jbise.2010.37093

[6] $\mathrm{Hu}, \mathrm{W}$. (2010) Identification of highly conserved do- mains in hemagglutinin associated with the receptor binding specificity of influenza viruses: 2009 H1N1, Avian H5N1, and Swine H1N2. Journal of Biomedical Science and Engineering, 3, 114-123. doi:10.4236/jbise.2010.32017

[7] $\mathrm{Hu}, \mathrm{W}$. (2010) Quantifying the effects of mutations on receptor binding specificity of influenza viruses. Journal of Biomedical Science and Engineering, 3, 227-240. doi:10.4236/jbise.2010.33031

[8] Hu, W. (2010) Subtle differences in receptor binding specificity and gene sequences of the 2009 pandemic H1N1 influenza virus. Advances in Bioscience and Biotechnology, 1, 305-314. doi:10.4236/abb.2010.14040

[9] Hu, W. (2010) Correlated mutations in the four influenza proteins essential for viral RNA synthesis, host adaptation, and virulence: NP, PA, PB1, and PB2. Natural Science, 2, 1138-1147. doi:10.4236/ns.2010.210141

[10] King, D., Miller, Z., Jones, W. and Hu, W. (2010) Characteristic sites in the internal proteins of avian and human influenza viruses. Journal of Biomedical Science and Engineering, 3, 943-955. doi:10.4236/jbise.2010.310125

[11] Hu, W. (2010) Highly conserved domains in hemagglutinin of influenza viruses characterizing dual receptor binding. Natural Science, 2, 1005-1014. doi:10.4236/ns.2009.29123

[12] $\mathrm{Hu}, \mathrm{W}$. (2010) Host markers and correlated mutations in the overlapping genes of influenza viruses: M1, M2; NS1, NS2; and PB1, PB1-F2. Natural Science, 2, 1225-1246. doi: 10.4236/ns.2010.211150

[13] Barr, I.G., Cui, L., Komadina, N., Lee, R.T., Lin, R.T., Deng, Y., Caldwell, N., Shaw, R. and Maurer-Stroh, S. (2010) A new pandemic influenza $A(H 1 N 1)$ genetic variant predominated in the winter 2010 influenza season in Australia, New Zealand and Singapore. Euro Surveill, 15, 19692.

[14] Stevens, J., Blixt, O., Glaser, L., Taubenberger, J.K., Palese, P., Paulson, J.C. and Wilson, I.A. (2006) Glycan microarray analysis of the hemagglutinins from modern and pandemic influenza viruses reveals different receptor specificities. Journal of Molecular Biology, 355: 11431155. doi:10.1016/j.jmb.2005.11.002

[15] Stevens, J., Blixt, O., Tumpey, T.M., Taubenberger, J.K., Paulson, J.C. and Wilson, I.A. (2006) Structure and receptor specificity of the hemagglutinin from an $\mathrm{H} 5 \mathrm{~N} 1$ influenza virus. Science, 312, 404-410. doi:10.1126/science. 1124513

[16] Matrosovich, M., Tuzikov, A., Bovin, N., Gambaryan, A., Klimov, A., Castrucci, M.R., Donatelli, I. and Kawaoka, Y. (2000) Early alterations of the receptor-binding properties of $\mathrm{H} 1, \mathrm{H} 2$, and $\mathrm{H} 3$ avian influenza virus hemagglutinins after their introduction into mammals. Journal of Virology, 74, 8502-8512. doi:10.1128/JVI.74.18.8502-8512.2000

[17] Karasin, A.I., West, K., Carman, S. and Olsen, C.W. (2004) Characterization of avian H3N3 and H1N1 influenza A viruses isolated from pigs in Canada. Journal of Clinical Microbiology, 42, 4349-4354. doi:10.1128/JCM.42.9.4349-4354.2004

[18] Liu, Y., Childs, R.A., Matrosovich, T., Wharton, S., Palma, A.S., Chai, W., Daniels, R., Gregory, V., et al. (2010). Altered receptor specificity and cell tropism of D222G hemagglutinin mutants isolated from fatal cases 
of pandemic A(H1N1) 2009 influenza virus. Journal of Virology, 84, 12069-12074.

doi:10.1128/JVI.01639-10

[19] Kilander, A., Rykkvin, R., Dudman, S. and Hungnes, O. (2010) Observed association between the HA1 mutation $\mathrm{D} 222 \mathrm{G}$ in the 2009 pandemic influenza $\mathrm{A}(\mathrm{H} 1 \mathrm{~N} 1)$ virus and severe clinical outcome, Norway 2009-2010. Euro Surveill, 15, 19498.

[20] Liu, Y., Childs, R.A., Matrosovich, T., et al. (2010) Altered receptor specificity and cell tropism of D222G Hemagglutinin mutants isolated from fatal cases of pandemic A(H1N1) 2009 influenza virus. Journal of Virology, 84, 12069-12074. doi:10.1128/JVI.01639-10

[21] Su, Y. Yang, H.Y., Zhang, B.J., Jia, H.L. and Tien, P. (2008) Analysis of a point mutation in H5N1 avian influenza virus haemagglutinin in relation to virus entry into live mammalian cells. Archives of Virology, 153, 2253-2261. doi:10.1007/s00705-008-0255-y

[22] Veljkovic, V., Niman, H.L., Glisic, S., Veljkovic, N., Perovic, V. and Muller, C.P. (2009) Identification of hemagglutinin structural domain and polymorphisms which may modulate swine H1N1 interactions with human receptor. BMC Structural Biology, 9, 62. doi:10.1186/1472-6807-9-62

[23] Veljkovic, V., Veljkovic, N., Muller, C.P., Müller, S., Glisic, S., Perovic, V. and Köhler, H. (2009) Characterization of conserved properties of hemagglutinin of $\mathrm{H} 5 \mathrm{~N} 1$ and human influenza viruses: possible consequences for therapy and infection control. BMC Structural Biology, 7, 9-21.

[24] Veljkovic, N., Glisic, S., Prljic, J., Perovic, V., Botta, M. andVeljkovic, V. (2008) Discovery of new therapeutic targets by the informational spectrum method. Current
Protein and Peptide Science, 9, 493-506. doi:10.2174/138920308785915245

[25] Katoh, K., Kuma, K., Toh, H. and Miyata, T. (2005) MAFFT version 5: Improvement in accuracy of multiple sequence alignment. Nucleic Acids Research, 33, 511518. doi:10.1093/nar/gki198

[26] Cosic, I. (1997) The resonant recognition model of macromolecular bioreactivity, theory and application. Birkhauser Verlag, Berlin.

[27] http://www.cdc.gov/flu/about/qa/1011 vac selection.htm

[28] Solovyov, A., Palacios, G., Briese, T., Lipkin, W.I. and Rabadan, R. (2009) Cluster analysis of the origins of the new influenza A(H1N1) virus. European Surveillance, 14, 19224.

[29] Wong, E.H., Smith, D.K., Rabadan, R., Peiris, M. and Poon, L.L. (2010) Codon usage bias and the evolution of influenza A viruses. Codon Usage Biases of Influenza Virus. BMC Evolutionary Biology, 10, 253. doi:10.1186/1471-2148-10-253

[30] Wanitchang, A., Jengarn, J. and Jongkaewwattana, A. (2011) The $\mathrm{N}$ terminus of PA polymerase of swine-origin influenza virus H1N1 determines its compatibility with PB2 and PB1 subunits through a strain-specific amino acid serine 186. Virus Research, 155, 325-333. doi:10.1016/j.virusres.2010.10.032

[31] Mehle, A. and Doudna, J.A. (2009) Adaptive strategies of the influenza virus polymerase for replication in humans. Proceedings of National Academy Science of U.S.A., 106: 21312-21316. doi:10.1073/pnas.0911915106

[32] Maurer-Stroh, S., Lee, R.T., Eisenhaber, F., Cui, L., Phuah, S.P. and Lin, R.T. (2010) A new common mutation in the hemagglutinin of the 2009 (H1N1) influenza A virus. PLoS Currency, RRN1162. 